\title{
Is Public Relations without a Future? A South African Perspective
}

\author{
Ben-Piet Venter, Faan Louw \\ International Business School, Beijing Foreign Studies University, Beijing, China \\ Email: ben-piet@hotmail.com \\ Received January $24^{\text {th }}, 2012$; revised February $29^{\text {th }}, 2012$; accepted April $2^{\text {nd }}, 2012$
}

\begin{abstract}
The praxis of public relations seems to be under threat, owing to a bad reputation among other things. However, it is a fundamentally important partner in the organization's value chain, and could be beneficial if used in a proper manner. This paper finds, however, that (at least in South Africa), public relations practitioners are not clear about their potential contribution to organizational value and success, and may be prone to be exploited by the "real" spin doctors - managers with little or no ethical conscience.
\end{abstract}

Keywords: Communication; Public Relations; Value; Value Chain

\section{Introduction and Literature Review}

Public relations may become extinct. Defined in South Africa as the "management, through communication, of the perceptions and strategic relations between an organization and its internal and external stakeholders" (Skinner, Von Essen, Mersham, \& Motau, 2007: p. 4), it is facing a number of issues threatening its very praxis. The term itself faces extinction if attempts to change its name are successful. The profession faces extinction if it cannot clearly define its organizational role. Integrating public relations with other business functions is under threat if it continues being outsourced. It faces ethical attrition if the practice of using public relations merely to put a spin on organizational misbehaviors continues. A study in South Africa investigated these issues (Venter, 2008).

Public relations is facing a number of challenges to its practice and academic standing. Some of these challenges were the focus of two studies conducted in South Africa among members of the Public Relations Institute of Southern Africa (PRISA) who are mostly public relations practitioners (Venter, 2004; Venter, 2008). Findings of these studies resonate with opinions of others who feel public relations to be at odds with management in many contexts.

A major cause of concern for public relations practitioners is the fact that public relations in the organization is not taken seriously, and that it is not used to its full strategic potential, but merely as a tool to "save" the organization from unsavory public comment. Rensburg \& Cant (2003) argue that public relations' role in the organization needs clarification; they are echoed by Steyn \& Puth (2000) who advocate the elevation of public relations to strategic management level, since it is a strategic, not technical, function. Skinner et al. (2007), and Cutlip, Center, \& Broom (2006) agree. Outsourcing public relations may reinforce its technician rather than strategist role.

Steyn \& Puth (2000), Parsons (2004), Gibson \& Gonzales (2006), Smythe, Dorward, \& Reback (1992), and Pedersen (2006) all point out that the term "public relations" has developed a bad reputation, and propose that it be renamed; a renaming that will remove negative associations with public relations. However, the challenge to public relations is greater than semantics. Van Slyke Turk (2006) argues that public relations should re-train its practitioners, and re-examine and restructure its practice and education. The discipline will benefit only if it reinvents itself as a responsible academic discipline firmly rooted in business a well as communication sciences. This argument is supported by the South African definition, which implies that public relations should use communication to build and maintain strategically significant organizational relationships.

In spite of these issues, the function of public relations is required in the modern organization; especially its communication expertise and relationship-building abilities. Jüttner, Christopher, \& Baker (2007) express a need for someone to manage relationships between marketing and the supply chain. Managing relationships is one of the key precepts of public relations.

Supply chain management is considered a major contributor to organizational success, and is defined as a process focusing on the integration and management of "the flow of goods and services and information through the supply chain in order to make it responsive to customer needs while lowering total costs" (Russell \& Taylor, 2006: p. 415). The emphasis in this flow falls on collaboration, cooperation, and communication among and between members of the supply chain. Communication and relationships as key concepts in supply chain management is identified not only by these authors.

Cravens \& Piercy (2006: pp. 311-313) describe relationships between the members of the supply channel, collaboration, information sharing, competitive positioning, and product promotion as important issues in supply chain management. While they mention relationships and information sharing, they do not mention public relations by name, although the reference to promotion (given the marketer's perspective on public relations) could be inferred to include public relations. They also mention communication as an important element in designing market-driven organizations (Cravens \& Piercy, 2006: p. 418). It is apparent that communication, information sharing, relationship-building and maintenance, and positioning of the organization as well as its product/s are key elements in the supply chain management approach. 
A concept closely related to supply chain management is its antecedent, value chain analysis. Doyle \& Stern (2006: pp. 82-84) view value chain analysis as a useful tool for analyzing utility and cost drivers. Value chain analysis helps managers to lower cost, while simultaneously improving utility. Corporate image is a utility driver, while the cost of communication is a cost driver. Organizations typically analyze all activities identified by the value chain by driving down costs while increasing utility, thus creating value for the customer and the organization.

Phillips \& Caldwell (2005: p. 347) state that organizations outsource those activities that they do not deem necessary for the delivery of value to customers. Is it an indication of the perceived low value of public relations that it is frequently outsourced, or is it the failure of public relations to create value?

Lee (2000: p. 33) argues that communication and relationships play a vital role in supply chain management by pointing out that good communication and "tight relationships" between the partners of the supply chain are prerequisites for success. Lummus, Vokurka, \& Krumwiede (2008) argue that the flow of information in the supply chain, through a variety of communication channels, improves integration of the supply chain. Min \& Mentzer (2004) underline the importance of company-wide training sessions that will support organizations in implementing and executing supply chain activities. These include relationship-building and communication. Arnulf, Dreyer, \& Grenness (2005) introduce the role that trust plays in the supply chain by stating that, without trust among the various partners, the supply chain is vulnerable. Communication is one way in which organizations build trust, while another is the building and maintenance of relationships between supply chain partners.

Legner \& Schemm (2008: p. 121) propose using the term "information supply chain", which focuses on the problems experienced in sharing information throughout the supply chain. They advocate that information be seen in two ways: transactional and contextual. Where transactional information deals with production-related information such as orders and shipping notes among others, contextual information will have a focus on "partner and product information". The understanding of contextual information may well be widened to include information on the organization's other activities, such as its social responsibility.

Ellinger (2007: p. 101) states that marketing and business education has been too functionally focused to "make the process oriented integrative decisions that are inherent to industry today". He advocates that marketing majors should spend more time and effort to study supply chain management. While his arguments centre on marketing, they are also true of public relations, still currently inclined to take a too narrow and functionalist approach to its role in the organization or the supply chain.

Against the brief theoretical overview of public relations, its position and function in the organization, it is important to point out that the praxis of public relations is in dire straits. Within the organization, the public relations function is typically placed either within the public relations department, within marketing, or outsourced. Participation at strategic management level therefore varies and thus the status of public relations. It does not receive the same level of recognition as finance, production, or human resources. Public relations practitioners are often from academic backgrounds with little rele- vance to management, such as communication, media studies, or journalism. This dichotomy between what public relations ought to be and what it is, is perhaps a natural consequence of a number of circumstances, not completely outside the boundaries of control of public relations practitioners. A number of threats for public relations as an occupation and science is visible on the horizon and must be accounted for as soon as possible.

The term "public relations" is negatively associated with unethical practices conducted in its name (Steyn \& Puth, 2000; Parsons, 2004; Gibson \& Gonzales, 2006), and it should be renamed. Proposed new names include "corporate communication, strategic communication, reputation management, corporate diplomacy". Arguments in favor of renaming centre round the changed role/focus/perception implied by the new name.

Renaming the discipline will not solve much, other than create confusion, and energy should rather be devoted to changing behaviors causing the bad reputation. Renaming is a short term solution diverting attention from those factors contributing to its bad name in the first place.

Public relations would benefit from fundamental restructuring and should be firmly rooted in business and communication sciences (Van Slyke Turk, 2006). Not all public relations practitioners are formally trained in the discipline (Venter, 2004; Newsom, Turk, \& Kruckeberg, 2004), and are recruited from other fields such as law, journalism, or marketing. These practitioners have little or no theoretical foundation in public relations or business management, and may well contribute to its low status in the organization and its unprofessional and even unethical image. The practice of appointing untrained public relations practitioners will only cease if the educational requirements of the discipline are addressed. This threat will disappear when decision-makers in organizations understand the need for recruiting and appointing adequately trained and educated public relations-trained practitioners.

Outsourcing public relations is globally practiced. Skinner et al. (2007) differentiate between "corporate" and "consulting" public relations, where the former situates public relations within the organization itself and the latter outside the realm of the organization. Newsom et al. (2004) refine this distinction by identifying "staff member", "agency employee" and "independent PR practitioner". Cutlip et al. (2000) provide further refinement by identifying six different permutations of public relations practice. The outsourcing of public relations, an option long used by organizations, leading to the formation of the public relations consultancy as a viable business in its own right, poses a threat to the functioning of public relations within the organization, especially as a significant contributor to the organization's strategic management. The outsourcing of public relations also leads to ethical problems, especially when consultancies are tempted to accept clients representing conflicting interests. In order to maintain a steady stream of income, consultancies may be less likely to act strictly in the ethical interests of the organization.

The term "public relations" is sometimes associated with "spin doctoring" (Gibson \& Gonzales, 2007; Sterne, 2008), presenting an obvious threat to its practice. However, is the discipline itself to be blamed for its spinning transgressions, or is it being used by marketing management using it to obtain favorable publicity or top management wishing to manipulate public opinion? If true that not public relations itself, but top management is indeed the real spin doctor, this threat should be 
removed.

The praxis of public relations is vulnerable to potential extinction. Threats identified in literature are found in practice as the results of a study conducted in South Africa show (Venter, 2008). We wanted to find out more about the challenges facing public relations identified by Venter (2008), and decided to do it in two phases. Phase one (reported in this paper) consists of a more in-depth statistical analysis of available data generated by Venter (2008), while phase two outlines new research.

\section{Methodology}

The methodology used could be described as exploratory, that is, it was not based on some theoretical construct in public relations. The methodology included an exploratory factor analysis to identify possible latent variables. Latent variables were constructed that were used in regression analysis. Regressions were constructed by selecting those variables that correlated meaningfully and appealed to logic and experience.

A structured self-reporting questionnaire taking between 10 15 minutes to complete was e-mailed to members of PRISA during April 2008. While 1239 questionnaires were sent out, 101 responses were received after four weeks, putting the response rate at $8.1 \%$, within acceptable levels even if low. However, it was felt that respondents had sufficient knowledge of public relations (most have in excess of 10 years' experience in the field of public relations), and by virtue of their paid-for membership of the official body PRISA had sufficient interest in the field of public relations to make a meaningful contribution to this research. In spite of limitations we decided to do a deeper statistical analysis of available data from Venter (2008) before embarking on new research.

The questionnaire results used in this analysis are based on the Likert scale construct (Likert, 1932; Spector, 1992). The Likert scale assigns numbers to questions in order to measure attitudes or beliefs. The respondents had to indicate whether they 1) strongly agree; 2) agree; 3) neither agree nor disagree; 4) disagree; or 5) strongly disagree. The important features of Likert scaling are:

- The respondent's ratings reflect some strength of the attitude or belief.

- The ratings for different questions can be added to obtain a summated index of the respondent on the attitude or belief being measured.

The popularity of the Likert scale for research in humanities and social sciences is undeniable. The Likert scale is de facto based on ordinal scales. The ordinal scale is the cause of substantial debate on how to analyze responses. This debate has the following major features:

- Individual items (questions) should not be used in the analysis.

- Parametric statistics should not be used to analyze individual observations.

- The summative approach is recommended in which individual questions are grouped according to predetermined (pilot study results) clusters also called latent variables using confirmatory factor analysis. Alternatively, exploratory factor analysis could be used to determine latent variables (DiStefano, Zhu, \& Mîndrilă, 2009).

- Cronbach's alpha is then used to test how well the variables included in the latent variable fit.

- The summated latent variables can then be used for further regression analysis.

The Likert scale questionnaire contained five different groups of questions. Each group of questions relate to some critical issue that public relations employees face on a daily basis. An explanatory factor analysis was done on each group of questions. Based on the obtained results, latent variables were developed by adding the identified variables and then dividing by the number of variables added. Those questions that were asked in the negative were reversed before the adding was done. Table 1 shows the different statistics related to the factor analyses that were done:

Table 1 shows some detail of the factor analysis outcomes. The Likert scale items, within their respective groups, do not correlate strongly with each other, as is confirmed by the factors identified within each grouping. This result was somewhat unexpected, since the questionnaire was designed around factors that were perceived to be common within groupings. Three reasons were identified to explain the poor performance of the questionnaire:

- Very few individuals will voluntarily admit to unethical practices.

- Public relations agency employees and "in-house employees" may respond differently to some of the questions.

- The relatively small number of observations used in the analysis. Almost 40 per cent of the questionnaires could not be used because of missing values.

Table 2 reports Cronbach's alpha for the different groupings used in the questionnaire. Cronbach's alpha measures internal consistency, that is, how closely related a group of scale items are as a group. A "high" value of alpha is often used as evidence that the items measure an underlying (or latent) construct. Table 1 confirmed that the different groups are not close to unit dimensional. Table 2 confirms the multidimensional nature of the different groups, since the unstandardized alpha coefficients rarely make it beyond 0.7 , even if some of the poorer performing scale items are deleted.

\section{Summary of Results}

The results from Tables $\mathbf{1}$ and $\mathbf{2}$ clearly indicate towards some data inadequacies, especially the number of useful observations. Because of this it was decided to focus on broad tendencies contained in the data rather than focusing on specific detail. The factor analysis revealed interesting insights in the opinions of respondents. Likert scale items were clustered into factors and assigned descriptive titles as shown in Table 3.

In coming to an understanding of the identified latent variables, it was decided to make certain assumptions describing the different latent variables. The assumptions are based on a literature survey by Venter (2008), and are reported in Table 4.

\section{Findings and Discussion}

The normative assumptions (Table 4) as generic descriptors of latent variables were used to develop a set of hypothesized relationships between the identified latent variables (lv) which is shown in Table 5. See Table $\mathbf{3}$ for full description of latent variables.

These relationships are not based on any theoretical construct. The hypothesized relationships are based on deductions from observed praxis of public relations. These relationships will be used to evaluate the results obtained from the regression analyses. Because of the data inadequacies it was decided not to use 
Table 1.

Factor analysis outcomes and test statistics.

\begin{tabular}{cccccc}
\hline Grouping & Items in scales & Factors & Chi-sq & p-val & Cum var expl \\
\hline B13 & 11 & 5 & 9.85 on 10 df & .454 & .55 \\
B14 & 6 & 2 & 2.95 on $4 \mathrm{df}$ & .566 & .43 \\
C15 & 11 & 3 & 15.95 on $25 \mathrm{df}$ & .916 & .44 \\
D16 & 10 & 3 & 15.76 on $18 \mathrm{df}$ & .609 & .42 \\
D17 & 12 & 5 & 17.93 on 16 df & .328 & .56 \\
\hline
\end{tabular}

Table 2.

Cronbach's alphas for the different groupings used in the survey.

\begin{tabular}{|c|c|c|c|c|c|}
\hline Groupings & Items in scale & Sample size & Unstandardised & Standardised & Likert scales excluded \\
\hline Survey & 50 & 62 & .78 & .8083 & \multirow{3}{*}{ B13_2, B13_3, B13_8, B13_11 } \\
\hline \multirow{2}{*}{ B13 } & 11 & 85 & .6099 & .6027 & \\
\hline & 7 & 85 & .6902 & .689 & \\
\hline \multirow[b]{2}{*}{ B14 } & 6 & 85 & .6524 & .6403 & \multirow[b]{2}{*}{ B14_1, B14_5 } \\
\hline & 4 & 85 & .7155 & .7194 & \\
\hline \multirow{2}{*}{$\mathrm{C} 15$} & 11 & 81 & .6013 & .6603 & \multirow{2}{*}{$\mathrm{C} 15 \_4, \mathrm{C} 15 \_6, \mathrm{C} 15 \_8, \mathrm{C} 15 \_9$} \\
\hline & 7 & 81 & .6662 & .6984 & \\
\hline \multirow{2}{*}{ D16 } & 10 & 77 & .6394 & .6927 & \multirow{2}{*}{ D16_3, D16_4, D16_5, D16_9 } \\
\hline & 6 & 77 & .6789 & .7181 & \\
\hline \multirow{2}{*}{ D17 } & 12 & 71 & .6949 & .6951 & \multirow{2}{*}{ D17_1, D17_4 } \\
\hline & 10 & 71 & .7005 & .7063 & \\
\hline
\end{tabular}

detailed regression results, but rather focus on the trend (positive or negative relationship) between the independent and dependent variables. Using Tables $\mathbf{4}$ and $\mathbf{5}$ it is possible to get a general impression of how the respondents perceived their unique positions in the public relations industry in South Africa.

- Regression 1: Mission: Public relations should strive for an environment with high mission compliance and avoid spin. As such, it should also support governance and be involved in mission development. If public relations has an ethical mandate, it could play a significant role in ethics guidance, since as a function it deals with relationships and trust between the organization and its stakeholders. The fact that respondents see it in a similar vein supports the involvement of public relations on a strategic level.

- Regression 2: Spin: Surprisingly, when strategic/ethics guidance is high, spin is also high. Could this be that respondents want to be involved in strategic/ethics guidance, but find themselves in high spin environments? The desire of public relations to be taken seriously as a strategic partner is clear in this regression. Respondents in high spin environments feel that they should be involved in providing mission and ethics guidance. That strategic/ethics guidance and spin correlate positively is untenable, since the correlation should be negative, where public relations provides guidance on, inter alia, ethics, thus reducing spin. It also points to the ethical conscience of those finding themselves in high spin situations, expressing a wish to help eliminate spin.

- Regression 3: Ethics: The negative correlation of outsourcing to ethics shows that respondents agree that outsourcing has a negative effect on ethical conduct. Outsourcing is thus a thorn in the ethical side of public relations practice. Should public relations be able to demonstrate the value it adds to the organization and defend its central role in the value chain, it would not be outsourced.

- Regression 4: Order-takers: The positive correlation of spin, as well as the negative correlation of training sufficiency to order-takers is not surprising, since order-takers will be prone to executing orders to put a spin on organizational misbehaviors; they will also, acting as technicians possibly without any full-rounded public relations training, perceive their training to be sufficient. That interdependence is positively, and outsourcing negatively, correlated to order-takers is puzzling. Our assumption was that greater awareness of interdependence would lead respondents to be less inclined to order-taking. It could be that order-takers perceive themselves to be dependent on others to complete their tasks. Those in outsourced environments are by definition order-takers. As seen previously, outsourcing creates a laboratory for unethical conduct, and outsourced agencies may be more inclined to put the spin into public relations.

- Regression 5: Strategic/ethics guidance: The positive correlations of mission, organizational ethics, and training sufficiency paint an interesting picture. A high sense of mission would lead to a high desire to be involved in strategy 


\section{B.-P. VENTER, F. LOUW}

Table 3.

Factor analysis.

\begin{tabular}{|c|c|c|}
\hline Factor & Questions & Cluster title \\
\hline D13fac1 & $\begin{array}{l}\text { - Public relations practitioners always act in an ethical manner (like telling the truth). } \\
\text { - All the workers in my organization understand its mission. } \\
\text { The organization's mission is communicated well to all employees and other stakeholders in the } \\
\text { organization. }\end{array}$ & Mission \\
\hline D13fac2 & $\begin{array}{l}\text { - People suspect that most organizations hide the truth from them. } \\
\text { Top management expects public relations practitioners to lie in order to save the organization's } \\
\text { reputation. }\end{array}$ & Spin \\
\hline D13fac3 & $\begin{array}{l}\text { - It is the job of public relations practitioners to always present the organization in a favorable } \\
\text { light. } \\
\text { Even when the organization does something wrong (like polluting the environment), it is the job } \\
\text { of public relations practitioners to defend the organization's actions. } \\
\text { - Public relations practitioners always act in an ethical manner (like telling the truth). }\end{array}$ & Ethics \\
\hline D13fac4 & - Top management expects public relations practitioners to do as they are told. & Order-takers \\
\hline D13fac5 & $\begin{array}{l}\text { - Public relations practitioners should provide guidance on ethics in my organization. } \\
\text { - Public relations should develop the organization's mission. }\end{array}$ & Strategic/ethics guidance \\
\hline D14fac1 & $\begin{array}{l}\text { - Customers in general get the service they are promised in advertising. } \\
\text { - When a company explains its actions to its publics, the explanation can be trusted. } \\
\text { - Organizations never tell lies to customers. } \\
\text { - Corporate social responsibility programs are sufficient to demonstrate the organization's } \\
\text { corporate citizenship. }\end{array}$ & Organizational ethics \\
\hline D14fac2 & $\begin{array}{l}\text { - It is not possible for organizations to practice good corporate governance since it is difficult and } \\
\text { expensive to comply. }\end{array}$ & Governance \\
\hline D14fac3 & $\begin{array}{l}\text { - Not enough is being done to safeguard consumers' rights. } \\
\text { - Customers in general get the service they are promised in advertising. }\end{array}$ & Consumer ethics \\
\hline D15fac1 & $\begin{array}{l}\text { - Public relations practitioners can benefit from more training in business-related fields of study. } \\
\text { In delivering support to all other line managers, public relations practitioners need training in all } \\
\text { business functions. } \\
\text { - In order to do my job well, I have to have a relevant tertiary qualification. } \\
\text { - In order to function on a strategic level, public relations practitioners need training in strategic } \\
\text { management. } \\
\text { Public relations practitioners should cooperate closely with all other line managers in the } \\
\text { organization. }\end{array}$ & Interdependence \\
\hline $\mathrm{D} 15 \mathrm{fac} 2$ & $\begin{array}{l}\text { - Public relations practitioners are well-trained for their jobs. } \\
\text { - Public relations practitioners have a good understanding of how other business departments } \\
\text { function. } \\
\text { - Public relations practitioners do not understand the production/operations function of the } \\
\text { organization. } \\
\text { As public relations practitioner, I have a good relationship with all of the other functional } \\
\text { managers. }\end{array}$ & Interaction \\
\hline D15fac 3 & - Public relations practitioners can benefit from more training in business-related fields of study. & Business training \\
\hline D16fac1 & $\begin{array}{l}\text { - Public relations practitioners require training in business subjects like operations management to } \\
\text { add value to the organization. } \\
\text { - Other line managers need to be informed of the role that public relations plays in the } \\
\text { organization. } \\
\text { - Ethics training is an important component of the practice of public relations. } \\
\text { - Public relations as a function is generally disregarded by top management because they do not } \\
\text { understand the full impact of public relations activities. }\end{array}$ & Public relations value \\
\hline D16fac2 & $\begin{array}{l}\text { - Public relations practitioners require training in business subjects like operations management to } \\
\text { add value to the organization. } \\
\text { - Line managers other than public relations managers are not trained in communication } \\
\text { techniques, and should rely on public relations practitioners to manage relationships with groups } \\
\text { such as suppliers. } \\
\text { - My training in public relations prepared me well to perform my function in the organization. } \\
\text { - Public relations textbooks provide sufficient guidance for the "real world". }\end{array}$ & Training sufficiency \\
\hline D16fac3 & - Public relations as a function should NOT be outsourced. & Outsourcing \\
\hline
\end{tabular}


Table 4.

Normative assumptions.

\section{Normative assumptions}

\begin{tabular}{|c|c|}
\hline & Normative assumptions \\
\hline 1) Mission & Mission is the glue that binds all functions in the organization to a common purpose. \\
\hline 2) Spin & Covering up unethical transgressions of the organization's brand promise. \\
\hline 3) Ethics & Ethics of public relations. \\
\hline 4) Order-takers & Public relations practitioners are treated as technicians. \\
\hline 5) Strategic/ethics guidance & Public relations practitioners provide guidance on strategy development and ethics. \\
\hline 6) Organizational ethics & The way in which organizations treat stakeholders in light of the brand promise. \\
\hline 7) Governance & Commitment to good governance. \\
\hline 8) Interdependence & Cross-functional management ability. \\
\hline 9) Interaction & Public relations' interaction with other business functions. \\
\hline 10) Business training & Public relations practitioners require business training. \\
\hline 11) Public relations value & Appreciation of the value added by public relations. \\
\hline 12) Training sufficiency & Public relations training sufficiency. \\
\hline 13) Outsourcing & Outsourcing of public relations. \\
\hline
\end{tabular}

Table 5.

Hypothesized relationships.

\begin{tabular}{|c|c|c|c|c|c|c|c|c|c|c|c|c|c|}
\hline lv & 1 & 2 & 3 & 4 & 5 & 6 & 7 & 8 & 9 & 10 & 11 & 12 & 13 \\
\hline 1 & 1 & & & & & & & & & & & & \\
\hline 2 & - & 1 & & & & & & & & & & & \\
\hline 3 & + & - & 1 & & & & & & & & & & \\
\hline 4 & - & + & - & 1 & & & & & & & & & \\
\hline 5 & + & - & + & - & 1 & & & & & & & & \\
\hline 6 & + & - & + & - & + & 1 & & & & & & & \\
\hline 7 & + & - & + & - & + & + & 1 & & & & & & \\
\hline 8 & + & - & + & - & + & + & + & 1 & & & & & \\
\hline 9 & + & - & + & - & + & $+/-$ & + & + & 1 & & & & \\
\hline 10 & - & - & - & + & - & - & + & + & + & 1 & & & \\
\hline 11 & + & - & + & - & + & + & + & + & + & + & 1 & & \\
\hline 12 & + & - & - & - & + & + & + & + & + & - & - & 1 & \\
\hline 13 & - & + & - & + & - & - & - & - & - & - & - & + & 1 \\
\hline
\end{tabular}

development and ethics guidance. The same could be said of organizational ethics-where the sense of the ethical treatment of customers by organizations is high, the desire to provide ethics guidance would follow. However, and this is surprising, the perception that public relations training is sufficient is positively correlated to a wish to provide strategic guidance by developing the organization's mission opens a curious question: do public relations practitioners, and them alone, develop the organization's mission, or do they do so as part of a team? Literature on the subject is clear: Well-defined and executed mission is the result of collaborative efforts on management level, and not dominated by any single function. If some respondent feels his/her training to be sufficient (where literature questions the sufficiency of training), he/she may be tempted to grasp for a position (dominating mission development) out of ignorance. Public relations practitioners are generally not trained in business subjects, so how could they think they should play a leading role in a core business process? It is significant that governance is negatively correlated to strategic/ethics guidance. Surely ethics guidance implies that a person understands the necessity for good governance, regardless of costs of compliance? This shows a fundamental misunderstanding of ethics, and again speaks to public relations training.

- Regression 6: Organizational ethics: The fact that training 
sufficiency and order-takers are positively correlated by respondents is alarming, since someone with a highly developed sense of mission and governance should realize that his/her training needs to be supplemented, speaking to a false sense of security about his/her public relations training. A picture emerges of a public relations practitioner who realizes the importance of mission and governance, but who is insufficiently trained to participate in strategic actions, and in general only acts as technician (order-taker). This picture is further colored by the negative correlation between interaction and organizational ethics, with the respondents seemingly not realizing the importance of ethics as a team (indeed organizational) responsibility. Technicians are supportive of mission and governance, but unable to participate. This shows that public relations is marginalized and not necessarily seen as integral to organizational functioning.

- Regression 7: Governance: Public relations is marginalized in organizations where their added value is not appreciated, in spite of the fact that the practitioners thus marginalized believe in the importance of good governance. This indicates that organizations prone to spin will not necessarily regard advice supporting good governance, and also indicates that public relations and its proclaimed role as ethics guide is not fully seen as integral to organizational management. The positive correlation between training sufficiency and governance in this context shows that public relations curricula do in fact prepare practitioners for the importance of mission and governance. However, they are powerless to the real forces of spin-unscrupulous management. The marginalization of public relations may be attributed to its own false sense of training sufficiency.

- Regression 8: Interdependence: The fact that order-takers is positively correlated to interdependence is surprising, since interdependence by definition requires some measure of independent thought and action, and not only order-taking. This echoes a previous observation where order-takers positively correlated to interaction. This demonstrates the potential powerlessness of public relations practitioners in the organization, and their perceived added value. Respondents agree that interaction and interdependence are needed, but still act as technicians, showing a low regard for the value that public relations adds to the organization, further marginalizing it. The negative correlation between organizational ethics, governance, and interdependence is seen as a cry for help from respondents, wishing to portray these two areas as solely belonging to public relations, where they have indicated a strong wish to provide guidance on mission and ethics. This negative correlation again shows that respondents are grasping at functions that they can claim as their own, regardless of the fact that they need to work as part of a value chain of activities and across functions in the organization.

- Regression 9: Interaction: Why would spin correlate positively to interaction? Is it that the other business functions such as marketing expect public relations to spin? If so, this speaks directly to the misunderstanding discussed in literature that other business functions have of public relations as a tool to communicate propaganda. Public relations may have contributed to this picture by its own inability to demonstrate the critical value that it adds to the organization.
- Regression 10: Business training: The higher the commitment to governance, interdependence and the perceived added value by public relations, the higher the realization that business training is required by public relations practitioners. Thus, the greater the integration of public relations into the organization and its activities, the greater the need for public relations practitioners to be trained not only in public relations, but also in business subjects. This supports calls in literature for public relations to have a foundation in business, not only communication. It is significant that a greater need for business training is experienced where spin is low, and where public relations training is found to be insufficient. This supports the notion that public relations is an integral part of the organization wishing to be ethical, and where it may identify the need for well-trained public relations practitioners. It also supports the wish to be integrated into the organization.

- Regression 11: Public relations value: The positive correlation of training sufficiency and outsourcing to the appreciation of the value that public relations adds to the organization is disturbing. Previous regressions clearly show that outsourcing diminishes the value perception of public relations, while previous regressions also show that a perceived sufficiency of public relations training is detrimental to the strategic function of public relations. Could it be that those respondents working in outsourced agencies influenced these responses? It is natural to assume that an outside agency would perceive itself to be sufficiently trained, and would perceive itself to be adding value to the organization. If it were true that perceptions of the value added by public relations to the organization is positively correlated to outsourcing (as it is), it is a disturbing accusation against the praxis of public relations, and forms the foundation for its irritation at not being included in strategic management. If outsourced and consequently valued, it is a clear indication that public relations is not regarded as an essential valueadd component of the organization's value chain, and that it could and should be outsourced. If outsourced respondents perceive their public relations training to be sufficient, it also means that they are prone to act as technicians, with little input in the organization's strategic planning processes. This also helps to explain how organizational ethics in this regression negatively correlates to public relations value. If the organization is happy to delegate the spin to the outside company, it is demonstrating its low commitment to ethics, and expects the outside agency to handle media and other related public relations crises on its behalf and at arm's length.

- Regression 12: Training sufficiency: Interdependence leads to the perception that public relations training is sufficient. This could well mean (if read against the context of previous regressions) that technicians have to rely on other functions to execute their tasks.

- Regression 13: Outsourcing: This is a strong argument against outsourcing if the argument that public relations should be an integral strategic partner in the organization is accepted. If the perception of the value that public relations adds to the organization increases when the function is outsourced, it clearly shows that other business functions regard public relations as a non-essential business function that adds more value by being outsourced. It is in the fiscal interest of outsourced agencies to complain that governance 
is expensive and cumbersome, since governance expenses may erode retainer fees.

- Summary: Organizations need to guard against the ravages of spin. Continuing with practices contributing to spin such as the appointment of ill-trained public relations practitioners who are mere order-takers; outsourcing public relations to outside agencies who could not care about the organization's mission; defining public relations as a mere communication tool used to create favorable impressions at all costs all contribute to the diminishment of the organization's mission - the way in which it views and defines itself, and which is the guiding principle giving meaning to the very existence of the organization.

A positive influence from the guardians of public relations would greatly enhance the organizational mission. Public relations as a discipline and praxis should do the following:

- Restructure its body of knowledge to enhance professionalism not only of communication skills of public relations practitioners, but also its business-oriented foundation.

- Ensure high levels of professional integration with business by finding a model that will aid in integrating it into business processes.

- Lift the barriers of entry into public relations by enforcing strict ethical codes of conduct, based in an integrative model of public relations/business interaction.

- Stop the practice of outsourcing any but the most technical (printing, design) aspects of the public relations process.

The section on methodology in this paper outlined a small respondent base as a major shortcoming of this research. This shortcoming should be addressed by replicating this study using a larger sample base. The sample was also restricted to public relations practitioners, and the understanding of the problematic and solutions could be vastly expanded by including other business functions such as marketing, operations, and finance to establish whether they agree with the respondents cited in this study. This study could also be replicated in countries other than South Africa.

Research should also be conducted to describe and understand the specific value that public relations should add to the organization within the understanding of the value chain. Future research should also focus on the ethical role of public relations in the organization, so that it may be safeguarded against manipulation by unethical managers.

The research reported in this article shows a readiness among respondents to accept a potential realignment of the role of public relations in the organization, whereby:

- Public relations is not outsourced, but rather woven into the fabric of organizations.

- Public relations takes a more active role as the organization's ethical conscience.

- Public relations re-examines its body of knowledge and theory base to expand its organizational role.

This compels the authors to revisit the definition of public relations given in the introduction of this article:

"Public relations is managing value-added communication and relationship-building activities to support the organization in its strategic goals of building maintaining strategically significant relationships with internal and external stakeholders".

It is the contention of this article that a realigned public relations function, whereby it serves the entire organization as communication technician on the one hand, and a strategic and ethical rudder on the other, may contribute measurably to or- ganizational credibility, relationships and, thus, organizational value. The answer to this realignment may well lie in a discussion on Porter's value chain analysis.

\section{Acknowledgements}

This article is, in part, based on the doctor's thesis of B. P. Venter at the Cape Peninsula University of Technology. His study leader, Prof. Johann van der Merwe, is hereby acknowledged.

\section{REFERENCES}

Arnulf, J. K., Dreyer, H., \& Grenness, C. E. (2005). Trust and knowledge creation: How the dynamics of trust and absorptive capacity may affect supply chain management development projects. International Journal of Logistics: Research and Applications, 8, 225-236.

Cravens, D. W. \& Piercy, N. F. (2006). Strategic marketing (8th ed.). Boston, MA: McGraw-Hill.

Cutlip, S. M., Center, A. H., \& Broom, G. M. (2006). Effective public relations (9th ed.). Upper Saddle River, NJ: Pearson Prentice Hall.

DiStefano, C., Zhu, M., \& Mîndrilă, D. (2009). Understanding and using factor scores: Considerations for the applied researcher. Practical Assessment, Research \& Evaluation, 14, 1-11.

Doyle, P., \& Stern, P. (2006). Marketing management and strategy (4th ed.). Upper Saddle River, NJ: Pearson.

Ellinger, A. E. (2007). Making supply chain management relevant for marketing majors. Marketing education review, 17, 101-106.

Gibson, D. \& Gonzales, J. L. (2006). Elegant understatement: A new paradigm for public relations practice. Public relations quarterly, 51, 13-19.

Jüttner, U., Christopher, M., \& Baker, S. (2007). Demand chain management-Integrating marketing and supply chain management. Industrial Marketing Management, 36, 377-392.

Lee, H. L. (2000). Creating value through supply chain integration. Supply Chain Management Review. URL (last checked 16 September 2007). http://www.scmr.com/article/CA151843.html?q=hau+lee []

Legner, C., \& Schemm, J. (2008). Toward the inter-organizational product information supply chain-Evidence from the retail and consumer goods industries. Journal of the Association for Information Systems, 9, 119-150.

Likert, R., (1932). The method of constructing an attitude scale. Archives of Psychology, 140, 44-53.

Lummus, R. R., Vokurka, R. J., \& Krumwiede, D. (2008). Supply chain integration and organizational success. SAM Advanced Management Journal, 73, 56-63.

Min, S., \& Mentzer, J. T. (2004). Developing and measuring supply chain management concepts. Journal of Business Logistics, 25, 6399. doi:10.1002/j.2158-1592.2004.tb00170.x

Newsom, D, Turk, J. V., \& Kruckeberg, D. (2004). This is PR: The realities of public relations (8th ed.). Belmont, CA: Thomson Wadworth.

Parsons, P. J. (2004). Ethics in public relations: A guide to best practice. London: Kogan Page.

Pedersen, W. (2006). Why "corporate PR" when "corporate diplomacy" flows more trippingly on the tongue-And is much more accurate? Public Relations Quarterly, 51, 10-11.

Phillips, R., \& Caldwell, C. B. (2005). Value chain responsibility: A farewell to arm's length. Business and Society Review, 110, 345-370. doi:10.1111/j.0045-3609.2005.00020.x

Rensburg, R., \& Cant, M. (Eds.) (2003). Public relations: South African perspectives. Sandown: Heinemann.

Russell, R. S., \& Taylor, B. W. (2006). Operations management: Quality and competitiveness in a global environment (5th ed.). Hoboken, NJ: John Wiley \& Sons.

Skinner, C., Von Essen, L., Mersham, G., \& Motau, S. (2007). Handbook of public relations (8th ed.). Cape Town: Oxford University Press.

Smythe, J., Dorward, C., \& Reback, J. (1992). Corporate reputation: 


\section{B.-P. VENTER, F. LOUW}

Managing the new strategic asset. London: Century Business. Spector, P. E. (1992). Summated rating scale construction. Newbury Park, CA: Sage.

Sterne, G. D. (2008). Business perceptions of public relations in New Zealand. Journal of communication management, 12, 30-50.

Steyn, B., \& Puth, G. (2000). Corporate communication strategy. Sandown: Heinemann.

Van Slyke Turk, J. (2006). The professional bond-Public relations and the practice. Commission on Public Relations Education.

Venter, B. P. (2004). The role perceptions of public relations practitioners in South Africa. Unpublished master's thesis, Cape Town: Cape Technikon,.

Venter, B. P. (2008). Realignment of public relations in the value chain for improved organizational ethics in South Africa. Dtech Thesis, Cape Town: Cape Peninsula University of Technology. 